\title{
KONTEKSTUALISASI MATERI DALAM PEMBELAJARAN
}

\author{
Oleh: \\ Muhamad Parhan \\ Universitas Pendidikan Indonesia \\ parhan_muhamad@rocketmail.com
}

\begin{abstract}
ABSTRAK
Pembelajaran merupakan sebuah sarana transfer nilai-nilai ajaran hidup dan kehidupan yang ada dalam materi pelajaran ke dalam kehidupan riil peserta didik. Selain itu, pembelajaran merupakan kerja budaya yang menuntut peserta didik untuk selalu mengembangkan potensi dan daya kreativitas yang dimilikinya agar tetap survive dalam hidupnya. Karena realitas kehidupan manusia mengalami perubahan yang begitu cepat, baik perubahan sosial, proses transformasi budaya yang begitu deras, kesenjangan ekonomi serta pergeseran nilai-nilai kemanusiaan. Prinsip yang digunakan dalam pembelajaran harus menanamkan peserta didik bagaimana belajar dan menilai kegunaan belajar itu bagi dirinya. Belajar bukan sekedar aktivitas kognitif saja, melainkan juga sebuah proses yang terjadi dalam diri individu yang melibatkan seluruh bagian atau domain yang ada, seperti emosi atau perasaan, komunikasi yang terbuka dan nilai-nilai yang dimiliki oleh setiap peserta didik. Sehingga tujuan pendidikan meliputi tujuan yang bersifat kognitif, menjadi individu yang bertanggung jawab, penuh perhatian terhadap lingkungannya dan mempunyai kedewasaan emosi dan spiritual dapat tercapai dengan baik.
\end{abstract}

\section{Kata Kunci: Pembelajaran Kontekstual, Materi Pembelajaran}

\section{PENDAHULUAN}

Pembelajaran merupakan

sebuah sarana transfer nilai-nilai ajaran hidup dan kehidupan yang ada dalam materi pelajaran ke dalam kehidupan riil peserta didik. Selain itu, pembelajaran merupakan kerja budaya yang menuntut peserta didik untuk selalu mengembangkan potensi dan daya kreativitas yang dimilikinya agar tetap survive dalam hidupnya. Karena realitas kehidupan manusia mengalami perubahan yang begitu cepat, baik perubahan sosial, proses transformasi budaya yang begitu deras, kesenjangan ekonomi serta pergeseran nilai-nilai kemanusiaan. Prinsip yang digunakan dalam pembelajaran harus menanamkan peserta didik bagaimana belajar dan menilai kegunaan belajar itu bagi dirinya. Belajar bukan sekedar aktivitas kognitif saja, melainkan juga sebuah proses yang terjadi dalam diri individu yang melibatkan seluruh bagian atau domain yang ada, seperti emosi atau perasaan, komunikasi yang terbuka dan nilainilai yang dimiliki oleh setiap peserta didik. Sehingga tujuan pendidikan meliputi tujuan yang bersifat kognitif, menjadi individu yang bertanggung jawab, penuh perhatian terhadap lingkungannya dan mempunyai kedewasaan emosi dan spiritual dapat tercapai dengan baik. Pendidikan harus dikembangkan sebagai pengayaan nilai-nilai spiritual dan religiusitas dalam kehidupan nyata peserta didik. Karena peserta didik menurut (Sukring, 2013, hlm. 89) merupakan salah satu komponen 
manusia yang menempati posisi sentral dalam proses pendidikan. Peserta didik berkedudukan sebagai makhluk yang sedang berada dalam proses perkembangan dan pertumbuhan menurut fitrahnya masing-masing, sehingga peserta didik menurut (Desmita, 2009, hlm. 39) memerlukan bimbingan dan pengarahan yang konsisten menuju ke arah titik optimal kemampuan fitrahnya, atau juga sering disebut raw material (bahan mentah). Dalam pengertian ini mengisyaratkan bahwa peserta didik senantiasa tumbuh dan berkembang ke arah positif, secara alamiah (nature), yang memerlukan bantuan dan bimbingan orang lain, dalam hal ini bimbingan dan bantuan itu hadir dari sosok pendidik yang ada di sekolah.

\section{PEMBELAJARAN KONTEKSTUAL}

Pendidikan yang baik
seharusnya dirancang untuk menggabungkan pengetahuan dan tindakan. Selain itu, pendidikan juga mengisyaratkan tujuan-tujuan pembelajaran tertentu yang berupa keterampilan-keterampilan dasar dan penanaman sifat-sifat pribadi, serta kemampuan interpersonal. Dengan demikian, kegiatan pembelajaran akan lebih konkret, lebih realistik, lebih aktual, lebih nyata, lebih menyenangkan, dan lebih bermakna. Kegiatan pembelajaran yang dapat membelajarkan peserta didik dan dapat menggabungkan antara pengeahuan dan tindakan serta teraplikasikannya pembelajaran dengan kehidupan, merupakan core dari pembelajaran kontekstual.

Pembelajaran kontekstual sebagai disiplin ilmu diharapkan dapat meningkatkan hasil belajar yang lebih berkualitas, lebih mendorong timbulnya kreativitas dan produktivitas serta efisiensi dan efektivitasnya yang lebih terasa. Pembelajaran secara kontekstual melibatkan semua alat indra secara serentak sehingga kegiatan pembelajaran menjadi lebih aktual, konkret, realistik, nyata, menyenangkan, dan bermakna. Hal ini dikarenakan pendidikan secara mendasar menurut (Tafsir, 2011, hlm. 6) adalah sebuah usaha meningkatkan diri dalam segala aspeknya, dengan melakukan bimbingan terhadap seluruh asepknya. Sebagaimana (Marimba, 1962, hlm. 15) menyatakan bahwa pendidikan merupakan sebuah bimbingan atau pimpinan secara sadar oleh pendidik terhadap perkembangan jasmani dan ruhani si terdidik menuju terbentuknya kepribadian yang utama. Kepribadian yang utama adalah pribadi yang dalam arti satunya niat, ucap, pikir, perilaku, dan tujuan yang direalisasikan dalam kehidupan (Sauri, 2006, hlm. 36). Sehingga diperlukan pembelajaran yang berdasarkan pada pendekatan kontekstual, yang intinya suatu pembelajaran yang memperhatikan potensi-potensi yang dimiliki oleh peserta didik dan dengan selalu mengaitkan pembelajaran dalam konteks dan pengalamanpengalaman hidup yang beraneka ragam serta situasi-situasi atau masalah-masalah hidup peserta didik.

Laboratorium pembelajaran
adalah kehidupan itu sendiri.
Pendidikan harus dipandang
sebagai sebuah proses hidup bukan
hanya persiapan untuk kehidupan
yang akan datang, pendidikan yang
sesungguhnya


berkesinambungan dengan

kehidupan sosial. "Education, in its broadest sense, is the means of this social continuity of life" (Dewey, 1964, hlm. 2). Lebih jauh dikatakan bahwa proses pembelajaran harus melibatkan peran serta aktif peserta didik, yang melibatkan kontrol sosial yang meminimalisir pembelajaran yang hanya menjadi kegiatan pentransferan materi-materi yang diberikan kepada individual saja, tanpa ada disposisi mental dan emosional, sebagaimana (Dewey, 1964, hlm. 325), mengemukakan:

When learning is a phase of active undertakings which involve mutual exchange, social control enters into the very process of learning. When the social factor is absent, learning becomes a carrying over of some presented material into a purely individual consciousness, and there is no inherent reason why it should give a more socialized direction to mental and emotional disposition.

Melalui interaksi dengan lingkungan dan menginterpretasi terhadap pengetahuan dan pengalaman hidup tersebut, maka peserta didik dapat mengkonstruksi makna-makna dan nilai-nilai pembelajaran untuk diinternalisasikan dalam kehidupannya. Sebagaimana (Hamruni, 2012, hlm. 142) menjelaskan bahwa membangun pengetahuan baru dalam struktur kognitif peserta didik didasarkan kepada pengalaman. Pengetahuan bukanlah seperangkat fakta-fakta, konsep atau kaidah yang siap untuk diambil dan diingat (Komalasari,
2013, hlm. 11). Pengetahuan dibangun oleh manusia sedikit demi sedikit, yang hasilnya diperluas melalui konteks yang terbatas (sempit) dan tidak muncul dengan sendirinya. Senada dengan itu (Gredler, 2011, hlm. 25) mengemukakan bahwa pengetahuan itu adalah hasil kontruksi manusia dalam membentuk, membangun, dan menghubungkannya dengan pengetahuan baru melalui pengalaman nyata. Lingkungan sangat mempengaruhi dalam menentukan kepribadian peserta didik, lingkungan dapat mendukung kematangan proses berpikir peserta didik, menyediakan model yang dapat dijadikan pedoman oleh peserta didik, dan lingkungan memberikan kesempatan belajar kepada peserta didik. Sebagaimana (Hurlock, 1898, hlm. 79) mengemukakan:

The environment influences the personality pattern most notably in three ways: it encourages or stunts the maturation of hereditary potentials; it provides personality pattern models which the individual uses as guide; and it either provides or denies needed learning opportunities.

Pembelajaran yang baik harus mampu menghadirkan suatu konstruksi wacana sosial yang relefan dengan kehidupan masyarakat serta mampu ditransformasikan secara sistematik dalam masyarakat. Materi dalam pembelajaran di sekolah tidaklah dalam keadaan statis, tetapi terusmenerus membutuhkan suatu pengayaan dalam berbagai aspeknya. Jadi pembelajaran di sekolah perlu mengacu pada suatu 
konteks sosial dan kultural yang sedang berkembang, di samping tentunya harus mengacu secara normatif dan teologis dengan doktrindoktrin agama. Sedangkan dengan melihat pada pendidikan yang berlangsung di dunia sekolah dewasa ini, dijumpai praktik pendidikan yang kurang menarik dari sisi materi yang diajarkan dan cara penyampaian yang digunakan, (Muhaimin, 2012, hlm. 23) mengemukakan bahwa materi pembelajaran terlalu didominasi oleh masalah-masalah yang bersifat normatif, ritualistik dan eskatologis, dan kurang memberi peluang untuk menelaah secara kritis materi yang akan disampaikan, sehingga menurut (Freire, 2009, hlm. 52) materi yang diajarkan di sekolah bukannya membumi, malah tercerabut dari pengalaman keseharian peserta didik. Model pendidikan seperti ini hanya berfungsi untuk mematikan kreativitas peserta didik, karena lebih mengedepankan aspek verbalisme. Kontekstualisasi materi pembelajaran perlu disusun agar lebih bermakna bagi kehidupan peserta didik. Hal ini bisa dilakukan dengan memilah-milah materi yang tekstual dan meteri yang dapat dikaitkan dengan hal-hal riil, kemudian meneliti konteks kehidupan peserta didik sehari-hari secara cermat, baik kehidupan pribadi, keluarga, masyarakat, sosial, budaya dan sebagainya sehingga materi pelajaran dapat dikaitkan dengan berbagai konteks yang nyata tersebut. Hal ini senada dengan (Slavin, 2009, hlm. 3) yang menyatakan bahwa pendidik dalam proses pembelajaran tidak hanya memberikan pengetahuan kepada peserta didik, tetapi peserta didik harus membangun pengetahuan itu dalam pikiran mereka sendiri.
Karena pembelajaran menurut (Schunk, 2012, hlm. 6) bisa terjadi melalui pengalaman (learning occurs through experience), karena perubahan-perubahan yang terjadi tergantung pada lingkungan, yang berfungsi untuk perkembangan individu. Lebih jauh dikatakan bahwa "learning is an enduring change in behavior, or in the capacity to behave in a given fashion, which results from practice or other forms of experience" (Schunk, 2012, hlm. 3). Menurutnya pembelajaran merupakan perubahan yang bertahan lama dalam perilaku, atau dalam kapasitas berperilaku dengan cara tertentu, yang dihasilkan dari praktik atau bentuk-bentuk pengalaman lainnya, lebih jauh dikatakan bahwa pembelajaran harus memiliki kriteria-kriteria sebagai berikut: learning involves change, learning endures over time, dan learning occurs through experience. Hal ini sejalan dengan (Syah, 2013, hlm. 10) yang menyatakan bahwa pembelajaran dipergunakan untuk menyempurnakan perkembangan individu dalam menguasai pengetahuan, kebiasaan, sikap, dan sebagainya. Lebih jauh (UUSPN tahun 2013 bab II pasal 3) menyebutkan bahwa proses akhir dari pendidikan itu bertujuan untuk berkembangnya potensi peserta didik agar menjadi manusia yang beriman dan bertaqwa kepada Tuhan Yang Maha Esa.

Pembelajaran hendaknya merupakan sebuah konsepsi yang dapat membantu pendidik untuk menggali isi mata pelajaran dengan situasi yang sebenarnya dan memotivasi peserta didik untuk dapat menemukan hubungan-hubungan pengetahuan dengan bagaimana 
penerapannya dalam kehidupan mereka. Pembelajaran yang terjadi tidak hanya menyampaikan materi yang teoretis dan abstrak, tetapi menyampaikan materi dengan dikontruksi dan menemukan nilai manfaat dalam setiap kali proses pembelajaran yang dilakukan, seingga peserta didik betul-betul dapat mengamalkannya dalam kehidupan nyata mereka sehari-hari.

Pembelajaran dengan menggunakan pendekatan kontekstual merupakan suatu strategi pembelajaran yang menekankan kepada proses keterlibatan peseta didik secara penuh untuk dapat menemukan materi yang dipelajari dan menghubungkannya dengan situasi kehidupan nyata, sehinga medorong peseta didik untuk dapat menerapkannya dalam kehidupan keseharian mereka. Proses pembelajaran dengan pendekatan kontekstual menekankan kepada proses keterlibatan peserta didik untuk menemukan materi, artinya proses belajar harus diorientasikan kepada proses pengalaman secara langsung, proses ini mengharapkan peserta didik tidak hanya menerima materi pelajaran, akan tetapi proses mencari dan menemukan sendiri materi pelajaran dengan bimbingan pendidiknya. Selain itu proses pembelajaran harusnya dapat mendorong peserta didik untuk dapat menemukan hubungan antara materi yang dipelajari dengan situasi kehidupan nyata, artinya peserta didik harus diarahkan untuk dapat menangkap hubungan antara pengalaman belajar yang didapat di sekolah dengan kehidupan nyata mereka sehari-hari. Hal ini sangatlah penting, karena ketika peserta didik dapat mengkorelasikan materi yang ditemukan dengan kehidupan nyata, maka materi tersebut akan lebih bermakna secara fungsional dan materi yang dipelajarinya akan tertanam erat dalam memori peserta didik, sehingga tidak akan mudah dilupakan. Karena pembelajaran dengan menghadirkan masalahmasalah yang semakin kuat relevansinya kepada peserta didik akan lebih menantang bagi peserta didik (Schunk, 2012, hlm. 366), sependapat dengan itu (Hamruni, 2012, hlm. 135) mengemukakan bahwa pengetahuan bukanlah hasil pemberian dari orang lain seperti pendidik, tetapi hasil dari proses merekontruksi yang dilakukan peserta didik. Menurut (Johnson, 2002, hlm. 24-25) menjelaskan bahwa:

CTL is a holistic system. It consists of interrelated parts that, when interwoven, produce an effect that exceeds what any single part could achieve. CTL, the distinctive educational approach made up of these parts, does more than guide students to join academic subjects with the context of their own aircumstances. It also engages students in exploring the meaning of "context" itself.

Menurut

Johnson

pembelajaran kontekstual merupakan sebuah sistem yang menyeluruh yang terdiri dari bagianbagian yang saling terhubung, jika bagian-bagian ini terjalin satu sama lain, maka akan dihasilkan pengaruh yang melebihi hasil yang diberikan bagian-bagiannya secara terpisah. Pembelajaran kontekstual 
merupakan suatu pendekatan pendidikan yang melakukan lebih dari sekedar menuntun peserta didik dalam menggabungkan subjeksubjek akademik dengan konteks keadaan mereka sendiri dengan melibatkan peserta didik dalam mencari makna "konteks" itu sendiri. Lebih jauh dikatakan (Johnson, 2002, hlm. 25), menurutnya pembelajaran kontekstual adalah:

The CTL system is an educational process that aims to help students see meaning in the academic material they are studying by connecting academic subjects with the context of their daily lives, that is, with the context of their personal, social, and cultural circumstances. To achieve this aim, the system encompasses the folowing eight components: making meaningful connections, doing significant work, selfregulated learning, collaborating, critical and creative thinking, nurturing the individual, reaching high standards, using autentic assessment.

Pembelajaran kontekstual lebih lanjut dikatakan Johnson, menurutnya pembelajaran kontekstual merupakan sebuah proses pendidikan yang bertujuan untuk menolong peserta didik melihat makna di dalam materi akademik yang mereka pelajari dengan cara menghubungkan subjek-subjek akademik dengan konteks dalam kehidupan nyata mereka, yaitu dengan konteks keadaan pribadi, sosial dan budaya mereka. Untuk mencapai tujuan ini, sistem tersebut meliputi delapan komponen berikut: membuat keterkaitan-keterkaitan yang bermakna, melakukan pekerjaan yang berarti, melakukan pembelajaran yang diatur sendiri, melakukan kerjasama, berpikir kritis dan kreatif, membantu individu untuk tumbuh dan berkembang, mencapai standar yang tinggi, dan menggunakan penilaian autentik.

Senada dengan itu (Depdiknas, 2002, hlm. 34) memberikan konsep pembelajaran kontekstual, menurut depdiknas:

Pembelajaran kontekstual menyajikan sebuah konsep belajar yang membantu pendidik untuk dapat mengaitkan antara materi yang diajarkan dengan situasi dunia nyata peserta didik dan mendorong peserta didik membuat hubungan antara pengetahuan yang dimiliki dengan penerapan dalam kehidupan mereka sehari-hari.

Sementara (Komalasari, 2013, hlm. 6) menyebutkan bahwa:

Pembelajaran kontekstual merupakan konsep belajar dan mengajar yang membantu pendidik mengaitkan antara materi yang diajarkan dengan situasi dunia nyata peserta didik dan mendorong peserta didik membuat hubungan antara pengetahuan yang dimilikinya dengan 
penerapannya dalam

kehidupan mereka seharihari.

\section{Pembelajaran}

mengedepankan

dengan

pendekatan

kontekstual dapat mendorong peserta didik untuk dapat menerapkannya dalam kehidupan, ini berarti bahwa pembelajaran kontekstual bukan hanya mengharapkan peserta didik dapat memahami materi yang dipelajarinya, akan tetapi bagaimana materi pelajaran tersebut dapat mewarnai perilakunya dalam kehidupan keseharian mereka. Materi pelajaran dalam kontekstual bukan untuk ditumpuk dan disimpan di dalam otak semata dan kemudian dijadikan konsep teoretis yang abstrak. Hal ini seperti yang diungkapkan (Hamruni, 2012, hlm. 137) yang menyatakan bahwa materi bukan hanya diterima akan tetapi materi itu didapatkan, sehingga materi yang telah didapatkan dapat menjadi bekal bagi peserta didik dalam mengarungi dan menjalani kehidupan yang nyata. Pembelajaran harus berpusat pada peran aktif peserta didik dalam setiap kali proses pembelajarannya, karena materi akan menjadi milik peserta didik, apabila proses pembelajaran betul-betul melibatkan secara penuh peran peserta didik dalam mengkontruksi dan menemukan materi, hal ini seperti yang dikemukakan (Sanjaya, 2010, hlm. 155), menurutnya:

Contextual teaching and learning adalah suatu strategi pembelajaran yang menekankan kepada proses keterlibatan siswa secara penuh untuk dapat menemukan materi yang

$\begin{array}{lr}\text { dipelajari } & \text { dan } \\ \text { menghubungkannya dengan } \\ \text { situasi kehidupan } & \text { nyata } \\ \text { sehingga mendorong siswa } & \text { sing } \\ \text { untuk dapat menerapkannya } \\ \text { dalam kehidupan mereka. }\end{array}$

Senada dengan itu (Johnson, 2011, hlm. 66) mengemukakan bahwa pembelajaran kontekstual melibatkan peran peserta didik dalam mencari makna "konteks". Pembelajaran yang dilakukan dengan pendekatan kontekstual bertujuan untuk dapat membantu peserta didik dalam membuat hubungan yang bermakna (making meaningful conections), yaitu membuat hubungan antara subjek dengan pengalaman atau antara pembelajaran dengan kehidupan nyata peserta didik sehingga dapat dihasilkan pembelajaran yang lebih bermakna, sehingga materi pelajaran yang mereka pelajari dapat diaplikasikan secara nyata dalam kehidupan seharihari.

Agar pembelajaran pembelajaran kontekstual dapat berjalan dengan baik, menurut (Johnson, 2002, hlm. 24-26) harus memenuhi kriteria-kriteria seperti berikut:

1. Pembelajaran hendaknya membuat hubungan yang bermakna (making meaningful conections), yaitu membuat hubungan antara subjek dengan pengalaman atau antara pembelajaran dengan kehidupan nyata peserta didik sehingga dapat dihasilkan pembelajaran yang lebih bermakna, dan kebermaknaan inilah yang akan memberikan alasan peserta didik untuk belajar. 
2. Melakukan pekerjaan yang berarti (doing significant work), yaitu dapat melakukan pekerjaan atau tugas-tugas yang sesuai dengan kemampuan dan kemauan peserta didik.

3. Melakukan pembelajaran yang diatur sendiri (self regulated learning), yaitu: (1) peserta didik belajar melalui tatanan atau cara yang berbeda-beda, bukan hanya dengan satu model pembelajaran saja, karena peserta didik mempunyai talenta dan ketertarikan yang berbeda-beda;

membebaskan peserta didik menggunakan gaya belajar mereka sendiri, memproses dalam cara mereka mengexsplorasi ketertarikan masing-masing dan mengembangkan bakat dengan intelegensi yang beragam sesuai dengan selera mereka; (3) proses pembelajaran yang melibatkan peserta didik dalam aksi yang bebas mencakup kadang satu orang, biasanya satu kelompok. Aksi bebas ini dapat dirancang untuk menghubungkan pengetahuan akademik dengan konteks kehidupan keseharian peserta didik dalam mencapai tujuan yang lebih bermakna, dan tujuan ini dapat berupa hasil yang nampak maupun yang tidak nampak.

4. Proses pembelajaran kontekstual mengedepankan kerja sama (collaborating) yang merupakan sebuah proses pembelajaran yang dapat melibatkan peserta didik lebih aktif berinteraksi dengan peserta didik yang lainnya dalam suatu kelompok.

5. Menekankan berpikir yang kritis dan kreatif (critical and creative thinking), yaitu sebuah pembelajaran yang menekankan kepada proses yang jelas dan terorganisir dalam pembelajaran yang dapat digunakan dalam kegiatan mental, seperti penyelesaian masalah, pengambilan keputusan, menganalisis asumsi, menganalisis pendapat dan masukan, serta melakukan penelitian ilmiah, selain itu proses pembelajaran juga harus dapat mengevaluasi pembelajaran secara sistematis, dengan memupuk ide-ide asli dan pemahamanpemahaman baru setelah proses pembelajaran terjadi.

6. Pembelajaran kontekstual harus dapat membantu individu untuk dapat tumbuh dan berkembang (nurturing the individual), yaitu menjaga dan mempertahankan kemajuan individu. Hal ini dilakukan dengan memotivasi, mendukung, menyemangati, dan memunculkan gairah belajar peserta didik. Pendidik dalam proses pembelajaran harus dapat menstimulus yang baik terhadap motivasi belajar peserta didik selama dia melakukan proses belajar. Pembelajaran diharapkan mampu memberi pengaruh yang positif terhadap minat dan lingkungan belajar peserta didik.

7. Pembelajaran harus dapat mencapai standar yang tinggi 
(reaching high standars), dalam artian pendidik dapat menyiapkan peserta didik untuk mandiri, produktif dan cepat dalam merespons atau mengikuti perkembangan teknologi dan perkembangan zaman. Pembelajaran seperti ini dibutuhkan penguasaan pengetahuan dan keterampilan sebagai wujud jaminan untuk menjadi orang yang bertanggung jawab dalam mengambil keputusan.

8. Pembelajaran dapat menggunakan penilaian yang sesungguhnya secara menyeluruh (using autentic assessement) dalam artian penilaian ditujukan kepada peserta didik untuk menilai secara keseluruhan yang bertujuan untuk dapat menilai seluruh asfek yang dimiliki oleh peserta didik, baik itu kognitif, afektif, maupun psikomotor peserta didik. Yang diharapkan akan menjadi motivasi bagi peserta didik untuk menjadi manusia yang berdaya saing tinggi dan lebih unggul untuk menghadapi kehidupan yang sebenarnya. Penilaian ini berpusat pada tujuan, yang melibatkan keterampilan tangan, penerapan, dan kerjasama serta pemikiran tingkat tinggi yang berulangulang. Penilaian ini bertujuan agar peserta didik dapat menunjukan penguasaan dan keahlian yang sesungguhnya dan kedalaman berpikir dari pengertian, pemahaman, akal budi, kebijaksanaan dan kesepakatan.
Jelaslah bahwa pembelajaran kontekstual merupakan sebuah pembelajaran yang mengharuskan pendidik membongkar isi dari pelajaran yang disampaikan dan mengaitkan dengan situasi yang sebenarnya serta memotivasi peserta didik untuk dapat membuat dan menemukan hubungan-hubungan pengetahuan dengan penerapan di dalam kehidupan mereka sebagai anggota keluarga, warga negara, dan pekerja, serta mengaitkan di dalam kerja keras yang diperlukan dalam belajar. Hal ini sejalan dengan konsep yang dikemukakan oleh Blanchard (2001, hlm. 1), Bern \& Erickson (2001, hlm. 2) yang menjelaskan tentang pembelajaran kontekstual, menurutnya:

Contextual teaching learning is a conception of teaching and learning that helps teacher relate subject matter content to real world situation, and motivates students to make connection between knowledge and its aplications to their lives as family members, citizens, and workes engage in the hard work that learning requires.

Pembelajaran yang dilakukan dengan pendekatan kontekstual, maka nilai-nilai yang terdapat dalam materi pembelajaran dapat terinternalisasikan dalam diri peserta didik, dan pembelajaran dapat menjadi milik peserta didik, karena direkontruksi dan ditemukan secara nyata oleh peserta didik dalam proses pembelajarannya. Memang menginternalisasikan nilai-nilai materi pembelajaran tidak bisa terjadi dengan sendirinya, ini memerlukan metode dalam pembelajarannya, 
Tafsir (2008, hlm. 224-232) menjelaskan beberapa tahapan yang dapat dilakukan dalam menginternalisasikan nilai, yaitu knowing, doing, dan being. Senada dengan Tafsir, (Ramayulis, 2012, hlm. 515-516) menjelaskan:

Di dalam proses pembelajaran ada tiga bentuk proses pembelajaran yaitu: (1) transformasi pengetahuan (transformation of knowledge),

pengembangan keterampilan (development of skill), dan (3) penanaman nilai (internalization of value). Pengembangan pengetahuan yang akan dicapai adalah tahu, mengetahui. Pengembangan keterampilan yang akan dicapai adalah terampil melaksanakan. Penanaman nilai adalah apa yang diketahuinya menjadi miliknya dan menyatu dalam akhlak dan karakternya dengan selalu menggunakan dan memperaktikannya dalam kehidupan sehari-hari.

\section{SIMPULAN}

Pembelajaran dengan pendekatan kontekstual menjadikan peserta didik menjadi manusia yang benar-benar menjadi manusia yang benar, yakni pembentukan jati diri sebagai individu, makluk sosial, dan makhluk religius yang mensinergikan kecerdasan otak dan kecerdasan watak serta kecerdasan akhlak. Yang bertindak dalam kehidupan sehariharinya akan mencerminkan pribadi yang integrated dan utuh, yaitu pribadi yang dalam arti satunya niat, ucap, pikir, perilaku, dan tujuan yang direalisasikan dalam kehidupan
(Sauri, 2006, hlm. 36). Proses pembelajaran yang semula berpusat kepada pendidik (teacher oriened) beralih kepada keaktifan peserta didik dalam melakukan proses pembelajaran (studen oriented). Pembelajaran dengan menggunakan pendekatan kontekstual membuat pembelajaran dapat menemukan hubungan yang penuh makna (making meaningful conection) antara materi yang dipelajari dengan kehidupan nyata peserta didik, pembelajaran dilakukan dengan mengaitkan (relating) antara materi yang ada pada peserta didik dengan pengalaman baru yang mereka dapatkan. Proses pembelajaran menekankan peserta didik kepada pengalaman langsung (experiencing) dalam mengeksplorasi, menemukan, dan membentuk pengetahuan barunya. Pembelajaran kontekstual dapat mengaplikasikan (applying) antara materi yang telah didapat dengan pelaksanaannya dalam kehidupan nyata peserta didik, dengan menekankan proses kerja sama (cooperating) dalam pembelajaran yang dilakukan, baik itu antara pendidik dengan peserta didik maupun antara peserta didik yang satu dengan peserta didik yang lain.

\section{DAFTAR PUSTAKA}

Al-Ghazali. (2001). Terjemahan Minhajul Abidin Menuju Iman Sejati Merintis Jalan ke Surga. Bandung: Husaini.

Budimansyah, D. (2010). Penguatan Pendidikan Kewarganegaraan untuk Membangun Karakter Bangsa. Bandung Widya Aksara Press.

(2012). Perencanaan 


\section{Pembelajaran Berbasis \\ Karakter seri Pembinaan \\ Profesionalisme \\ Guru. \\ Bandung: Widya Aksara \\ Press.}

Berns, R. G. \& Erickson, P. M. (2001). Contextual Teahing and Learning The Highlight Zone: Research @Work No. 5, (Jurnal online) diakses dari: http:/www.nccte.org/publicati ons/infosynthesis/highlightzon e/highlight05/index.asp

Blanchard, A. (2001). Contextual

Teahing and Learning. diakses dari:

http://www.horizonshelpr.org/ contextual/contextual.htm-8k

Dewey, J. (1964). Democracy and

Education: An Introduction to the Philosophy of

Education. New York: The

Macmillan Company.

Desmita. (2009). Psikologi Perkembangan Peserta Didik: Panduan bagi Orangtua dan Guru dalam Memahami Psikologi Anak Usia SD, SMP, dan SMA. Bandung: PT. Remaja Rosdakarya.

Freire, P. (2008). Pendidikan Kaum Tertindas. Jakarta: Pustaka LP3ES Indonesia.

Hurlock, E. B. (1898). Personality Development. USA: Mc Graw-Hill Book Company.

Johnson, E. B. (2011). CTL: Contextual Teaching \& Learning: $\quad$ Menjadikan Kegiatan Belajar-Mengajar Mengasikan dan Bermakna, (terjemah Ibnu Setiawan).
Bandung: Kaifa.

(2002). Contextual Teaching and Learning: what it is and why it's here to stay. California: Corwin Press.

$\begin{array}{lrr}\text { Komalasari, K. } & \text { (2013). } \\ \text { Pembelajaran } & \text { Kontekstual } \\ \text { Konsep dan } & \text { Aplikasi. } \\ \text { Bandung: } & \text { PT } & \text { Refika } \\ \text { Aditama. } & & \\ \text { (2008). } & \text { Pengaruh } \\ \text { Pembelajaran } & \text { Kontekstual } \\ \text { dalam rendidikan } & \text { Pendiswa } \\ \text { Kewarganegaraan } & \text { Siswa } \\ \text { SMP. Disertasi PPs UPI. }\end{array}$

Majid, A. (2011). Menalar Nilai Edukasi Puasa. Bandung: CV. Maulana Media Grafika. . (2012). Islam Faktual. Bandung: CV. Maulana Media Grafika.

Muhaimin. (2012). Pengembangan Kurikulum Pendidikan Agama Islam di Sekolah, Madrasah, dan Perguruan Tinggi. Jakarta: PT Raja Grapindo Persada.

Salim, H. \& Kurniawan, S. (2012). Studi Ilmu Pendidikan Islam. Jogjakarta: Ar-Ruzz Media.

Schunk, D. H. (2012). Learning Theorries An Educational Perspective (Teori-Teori Pembelajaran: Perspektif Pendidikan). terjemah Eva Hamdiah, Rahmat Fajar. Edisi keenam, Yogyakarta: Pustaka Pelajar. (2012). Learning Theories An Educational Perspective. Boston: Pearson. 
http://ejournal.ihdn.ac.id/index.php/AW

Sauri, S. (2006). Pendidikan Berbahasa Santun. Bandung: PT Genesindo.

(2012). Pendidikan Karakter dalam Perspektif Islam, Bandung: Rizqi Press.

(2011). Filsafat dan Teosofat Akhlak, Kajian filosofis dan Teosofis tentang Akhlak, Karakter, Nilai, Moral, Etika, Budi Pekerti, Tatakrama, dan Sopan Santun. Bandung: Rizqi Press.

Suriasumantri, J. S. (2005). Filsafat Ilmu sebuah pengantar populer. Jakarta: Pustaka Sinar Harapan.

Tafsir, A. (2012). Ilmu Pendidikan
Islami. Bandung: PT.

Remaja Rosda Karya.

. (2012). Berjalan Menuju Langit: Rukun Islam sebagai Tarekat. Bandung: Simbiosa Rekatama Media.

(2006). Filsafat Pendidikan Islami: Integrasi Jasmani, Rohani dan Kalbu Memanusiakan Manusia. Bandung : PT. Remaja Rosda Karya.

Yusuf, S. \& Nurihsan, A. J. (2011). Teori Kepribadian. Bandung: PT. Remaja Rosdakarya.

Zainuddin, dkk. (1991). Seluk Beluk Pendidikan dari Al-Ghazali. Jakarta: Bumi Aksara. 